\title{
Enhancing Intensive Development: an Approach to Running the High-Level Applied Technical University
}

\author{
Liu Gailin, Niu Tongzhuang \\ Xi'an University of Technological Information \\ Xi'an, 710299, China \\ e-mail: luga888@163.com
}

\author{
Shi Panrong \\ School of Foreign Languages \\ Xijing University \\ Xi'an, 710132, China \\ e-mail: joseph_spring@sina.com
}

\begin{abstract}
China is a major country of education. With the development of China, its education is undergoing continuous reforms so as to adapt to the demand of social and economic development. The Ministry of Education, together with other two ministries, launched the "Opinions on Guiding Some Local Universities to Transform into Applied Universities", thus making the questions concerning applied technical talent training a hotspot of research. This paper puts forward some suggestions on the core elements worth considering in regard to the characteristics and development of the applied technical university.
\end{abstract}

Keywords-Applied Technical University; Intensive Development; Teaching Faculty; Binary Education; Double-Qualified Teacher

\section{INTRODUCTION}

The higher education in China falls into three forms: the research university, the applied technical university and the vocational college. These three differ from one another in terms of the orientation and aim of talent training, although problems arise. On one hand, the population of graduates has been continuously increasing, - for example, the number of college graduates in 2016 reached 7.65 million; on the other hand, since the objective of education for many universities is unanimously the training of elites, there exists homogenization among many universities and a severe situation of employment is facing these college graduates, thus making structural unemployment all the more obvious. As a matter of fact, in order to keep the structure of higher education agreeable with that of the future society as well as its economy, part of the universities or colleges need to transform into applied technical universities or colleges. In 2015, the Ministry of Education, the National Development and Reform Commission, and the Ministry of Finance jointly launched the "Opinions on Guiding Some Local Universities to Transform into Applied Universities", and so 600 colleges and universities did as suggested thereafter. How to train college students to be excellent applied technical talents has become a new education-related theme worthy of the present research.

\section{THE APPLIED TECHNICAL UNIVERSITY}

The applied technical university is a product of the transformation, upgrading and technological progress of all industries during the process of building socialist modernization in China. Based on the need of the development of real economy, it serves the innovation and accumulation of the technologies and skills of the country, takes the modern vocational education system as its starting point and directly gets involved into the regional industrial development, thereby becomes a new type of university that combines technical education for career, higher education and continuous education. It should be evident that the term "technical" in applied technical university refers to a "technology" in a broader sense, a proper name with the meaning of applied science and technology which contains science, knowledge, engineering, technology, art, etc.

Seen from its essential attribute, the applied technical university has the "high-level, specialization, technicality, and humanity" nature. "High-level" refers to "higher education", meaning the applied technical university, like other types of four-year universities which mainly offer undergraduate education, is a form of higher education training advanced professionals. "Specialization" refers to "specialized education", intended for training high-level professionals for all divisions of labor in the society. "Technicality" refers to "technical training", in that applied technologies and skills are characteristic of the types of talent training, scientific research, and social services, which is a significant feature distinct from that of research universities. "Humanity" refers to "humanistic cultivation", i.e., the applied technical university is to produce individuals and talents who should be equipped with all-around humanistic, scientific, professional and eco-ethic qualities. In one word, the applied technical university produces talents and individuals who are not merely instrumental, technical or skillful individuals equipped with professional technologies and skills, but rather, ones having a harmonious development of body and mind.

\section{ASPECTS WORTH CONSIDERING FOR BUILDING THE High-LEVEL APPLIED TECHNICAL UNIVERSITY}

\section{A. Ensuring the Fundamental Tasks in Building "Applied Technical Universities"}

One is to train applied technical college graduates; the other is to enhance the abilities of servicing the local place and the society substantially. 


\section{B. Setting the Goal and/or Orientation of Running the University}

The applied technical university is to train high-level applied technical talents, with "high-level" and "applied technology" as its two prominent orientations.

\section{Three Elements Needed for Training Talents}

Firstly, applied nature (in terms of the objective of education) - to highlight practice teaching, foster ability of using hands, and strengthen application. The would-be talents to be trained should have solid foundation of knowledge, powerful practical ability, and capable of comprehensively using theoretical knowledge to deal with real problems.

Secondly, technical nature (in terms of the content of education) - to master the form of knowledge, highlight technical expertise (i.e., high-level, advanced technological knowledge), and stress the integration of theoretical knowledge and practical knowledge.

Thirdly, high-level nature (in terms of the level of education) - to foster the general ability for a major field.

\section{Factors in Setting Majors and Courses}

Firstly, the combination of high-level and applied natures and of demands of the trade, development of regional economy and professional skills.

Secondly, the combination of theory and practice - the arrangements of course groups, the hours and proportion of lessons, the time segments of internship and practice, the depth and width of knowledge, levels of practice, etc.

Thirdly, the integration of practice into theoretical courses in the major, with emphasis on the mastery of new technologies and the comprehension and application of theoretical knowledge in practice - to combine specialties with industries, courses with the industrial structures, and production with studies.

\section{E. High-level Double Qualified Faculty}

Full-time teachers are the main body that undertake all the tasks ranging from teaching and research to discipline and specialty construction, therefore, high-level double qualified faculty are needed to conform with the applied technical university running. The Higher Education Research Institute drafted a document, "Opinions on Transformation of Local Universities", which requires that the full-time teachers - with both teacher's qualification and another professional qualification - occupy a percentage of up to $50 \%$ of full-time faculty.

\section{F. Platform Building}

Setting up platforms for experiment, training and practice needed to train applied technical talents must be practiceoriented, highlighting students' hands-on and attaching importance to theory guiding practical use.

\section{BUILDING THE FIRST-ClASS UNIVERSITY WITH INTENSIVE DEVELOPMENT AS A FOCUS}

It is suggested that to build a first-class applied technical university, connotation construction, or intensive development, should be enhanced first. Here are the urgent needs:

\section{A. To Reasonably Design the Training Program and Mode in order to Train Applied Technical talents}

In the new situation both at home and abroad, a sound training program is a key to training first-class applied technical talents. When it comes to working out an applied technical talent training program, the maker needs to fully investigate the specifications of demands for talents in related professions, industries, and companies, consider the conditions, advantages and features of running a university for certain majors, conduct full argument over the training program by holding meetings of the professional committee composed of professionals of the trade as well as internal and external experts, make a good top-down design and scientific planning, work out a scientific and feasible talent training program which conforms with the demand of applied technical university running and implement a binary educational mode, i.e., the "university plus enterprise (society)" model.

The first thing is to set the goal and specification of talent training, keep helping the students develop morally, intellectually, physically and aesthetically, and meanwhile stress the construction of professional ability system. Professional ability system is to be constructed from the following dimensions: liberal-education ability - basic ability in the major - core ability in the major - extended ability in the major - practical ability and methodical ability. The practical ability and methodical ability, among others, is important throughout the development of every ability, and every ability in the major ought to be further specified, thus optimizing and ensuring a scientific major course system: liberal education course - basic courses in the major - core courses in the major - extended courses in the major practical courses and methodical courses.

Next, the construction of a course system and courses themselves is the core of intensive development. Throughout the major course system, what ought to be considered are the position, function and credit, learning hours (both theory and practice) and testing methods of every course, module or practice stage in the whole major course system, and the relationships between liberal courses and major courses, compulsory courses and optional courses, basic major courses and major courses, limited selective major courses and free selective major courses, optional major courses and public optional courses, platform and module, theory and practice (experiment, training, and internship), course design and graduation design (thesis), density of courses and freedom degree of learning, all-round development and individualized training, and so on, and so forth. It is suggested that the syllabus (including course syllabus, course standard, and experiment syllabus) of every course, instead of merely the description of knowledge points of a certain course, should be explicit, a system of knowledge points, ability points and notional points should be constructed, and a course system standard ought to be established based on all this. 
The important point of fostering the students' professional ability is not making them master some simple operational skills, but rather, the process involving skills and technologies based on the combination of overt practical hands-on ability and covert mental or thinking ability. Besides, in fostering the practical ability, especially experiment ability, we should reduce the proportion of demonstrative experiment and increase that of the comprehensive, innovative and open-ended experiment that involves design, so as to help the students develop professional design ability and practical innovation ability.

All majors ought to show their own features in the training program. We should make our education local industry-, enterprise- and profession-oriented, and, through "reciprocal, win-win" university-enterprise cooperation with advanced companies, achieve the aim of co-building an applied technical talent community with real engineering technology as the background and engineering technology training as the main line, in order to raise the students' engineering technology awareness, engineering technology quality and practical ability concerning engineering technology.

\section{B. To Change Teaching Methods and Strengthening the Objectivity, Effectiveness and Practicality of Classroom Teaching in order to Enhance the Teaching Quality}

In order to educate applied technical talents, the teacher needs to change the traditional "teacher-centered", studentas-passive-recipient teaching method, implement the heuristic teaching idea and adopt different teaching methods, thus putting the "students-centered" teaching method into practice in terms of teaching aims, teaching design, teaching content selection, classroom teaching strategy, assignment of homework, ways of assessment, etc. During this process, the teacher gives first priority to students' subjectivity and practicality for the purpose of fostering their abilities of discovering problems, analyzing problems, solving problems, and applying theoretical knowledge to be innovative in practice. The teacher should, based on the contents of the course he/she is to teach, make explicit the teaching aims of every course, resolve the teaching contents, make sure of the teaching method(s), and adopt diversified teaching approaches. The teacher must firstly be clear about the aim of offering the course as well as its practical significance, manage to be clear about the teaching aims of the course before every class so as to employ more appropriate methods to facilitate the subjectivity of students, the objectivity of teaching, the applicability of knowledge and the practicality of skills. In addition, the teacher must abandon the traditional teaching method and mode of imparting knowledge and adopt the method by which the interest and activeness of the students can be aroused through getting involved in classroom activities, hence the development of their abilities of finding problems, analyzing problems, solving problems and innovating in practice, for instance, the problem-oriented, project-supported, task-oriented method used to inspire the students in thinking, encourage their teamwork, guide them in creation and invention, and combine theory with practice.

\section{To Change Students' Learning Habits in order to Foster Their Autonomy and Awareness of Practice}

All education is intended for students, who are the core, subject and internal factor of education itself, so the the work on guiding the students to change their fixed idea of the past that they stress knowledge itself but ignore its application or they emphasize the acquisition of knowledge but neglect the importance of thinking and innovation for the purpose of making them study actively and effectively. Therefore, the university needs to strengthen the cognition practice as well as practice in society and enterprise, guide the students to establish the cognition about the application and development of the major field of studies, and so set a goal for their future development. The university must provide mutual support, compensation and integration, on campus and off campus, between the university and the enterprise and society; the teacher needs to consciously consider student for the development of their autonomy awareness and innovation-awareness; the students need to learn to give up the thought of depending upon others, know about their autonomous rights and duties, manage their studies on their own, master knowledge with the sight of discovering things, making full use of all the time and chance available to walk out of the classroom and campus and go into the enterprise and society to put what they have into practice. Only when they are equipped with decent virtual quality, wide knowledge of humanistic and social sciences, strong communicating ability and unique innovation awareness and ability can they meet the demand for the quality required by the applied technical talents in social competition.

\section{To Build On-campus Practice and Training Platforms in order to Train Applied Technical Talents}

In addition to solid theoretical knowledge, the applied technical talents must also have satisfying practical and innovative abilities, hence diversification of the approaches to training them, for instance, to strengthen experiment and training within the university and real-environment practice off campus, thereby attain the special "binary education" feature.

We should take advantage of various conditions on campus to establish and create platforms of knowledge application and experience, build related labs for all majors, guide the students to prove and test the theoretical knowledge they have learned in class in order to more deeply understand it and therefore have a good command of it. The students must keep consolidating their practical abilities by engaging in their teachers' projects, taking part in innovation activities of all kinds of campus societies, autonomous innovation research and internships in enterprise.

\section{E. To Establish University-enterprise Cooperation and Implement Binary Education in order to Strengthen the Development of Students' Practical Skills}

The "binary education" mode refers to a mode of training talents jointly conducted by university and enterprise. The combination of work and study is an educational mode involving the cooperation of teaching and learning in university and engineering practice in enterprise, therefore 
the university may get feedback and demand from the enterprise more directly, train the students for specific aims, and produce talents who are required by the society by taking into consideration the student's skills as well as the market orientation. The university-enterprise cooperation enables the university and the enterprise to share information and resources, combines what the students learn in university with their practice in enterprise, allows the university and the enterprise to compensate each other with equipment and technology, and saves the cost of education for both sides, so it is a "win-win" mode.

At this point, Germany's applied technical talent training mode is worth learning from. The RWTH Aachen University in Germany gives first priority to the training of practical ability in the process of applied technical talent training by introducing experts into the university, running companies within the university and allocating the students in it. In this way, it has truly succeeded in integrating and facilitating work, learning and research and produced excellent applied technical talents.

\section{F. To Strengthen Faculty Construction in order to Ensure the Improvement of Teaching Quality}

Faculty members are the decisive factor of teaching quality. The teacher's teaching ability and methods may exert a direct influence upon the quality of teaching. Therefore, there must be a faculty that can meet the need of training applied technical talents. It is put forward in the "Opinions on Transformation of Local Universities" by the Higher Education Research Institute that the "double qualified" faculty occupy $50 \%$ of the full-time teachers. This makes it clear that applied technical university teachers must be equipped with the characteristics of "double qualification" and "double ability", - that is, the faculty members must have the skills that an engineer does, with decent theoretical knowledge and teaching skills as well as the capability of guiding students with their hands-on ability.

The "double qualified" faculty have the following abilities:

1) Decent professional ethics, as well as the quality and ability to teach and educate talents and conduct career guidance for the latter;

2) Qualifications of the trade and profession conforming to the majors to teach, as well as solid foundations of basic theory, knowledge and practical ability of the industry and profession and abilities to conduct market surveys and analyses, analysis of the trade, analyses of career and occupation position groups, thereby to adjust and reform teaching objectives, teaching contents, teaching methods and teaching means, attaching importance to the imparting of knowledge of the trade and career to students and the development of students' practical abilities, and to get involved in the development and innovation of specialties.

3) Decent abilities of social communication, interaction, organization and coordination, that is, the students must be able to not only interact and coordinate on campus but also communicate with professionals engaged in the enterprise and trade.
4) Decent management ability, that is, the ability to manage a class and a classroom teaching as well as the ability of managing an enterprise or trade, knowing the law of trade management and enterprise operation, and guide students to get involved in enterprise and trade management.

5) Adjustment and innovation abilities, that is, the ability to get accustomed to the need of the era of fast changing information, technology and economy, be innovative at work, organize and guide students to take part in creative activities.

6) Consciousness of finding and analyzing problems, which should be applied to classroom teaching and students' practice guidance. Training "double qualified" faculty guarantees that the first-class, high-level applied technical university is well constructed and smoothly run. The university can adopt the method of "introducing some", "sending some" and "recruiting some", through which it can introduce experienced, capable new teachers or train newlyrecruited teachers to improve their practical abilities; it can send teachers on job to companies to be trained in their practical abilities or receive cooperative training by the enterprise and the university; and it can invite experienced, qualified technicians and engineers to the university to provide guidance for the students, encourage and support the teachers in getting involved in social practice, and further facilitate the communication and cooperation between the university and the enterprise, thus improving the faculty's practical abilities, making them the high-quality, strongability faculty to meet the need of talent training for the applied technical university.

Applied technical talent training conforms with the need of the development of the country, and it is a right direction for in the future.

\section{REFERENCES}

[1] Q. D. Ma, "The Connotation of Applied Technical Talents and the Development of Local Universities," Journal of Vocational Education, 2015(4), pp. 35-38.

[2] Q. S. Meng, M. G. Zhai, "The Training Mode of Applied Technical Talents: Reform and Practice," Chinese University Science \& Technology, 2015(Z1), pp. 100-102.

[3] Ministry of Education, National Development and Reform Commission, Ministry of Finance. Opinions on Guiding Some Local Universities to Transform into Applied Universities [EB/OL]. (201710-21)[2015-11-16] http://www.gov.cn/xinwen/2015-11/16/content_5013165.htm.

[4] Q. G. Meng, "Thoughts on Training Applied Technical Talents," Beijing Education (Higher Education), 2017(4), pp. 15-18.

[5] Z. Liu, "A Probe into the Training Mode of Applied Technical Talents," China University Students Career Guide, 2014(8), pp. 55-59.

[6] T. Li, "A Probe into the Talent Training Mode for Applied Technical Talents in English Major in the Context of Local University Transformation and Development," Journal of Hubei University of Economics (Humanities and Social Sciences), 2015(2), pp. 192-193. 